\title{
Radio and Public Sphere To Participate In Information Community Development
}

\author{
Totok Wahyu Abadi ${ }^{1}$, Ilmi Usrotin Choiriyah ${ }^{2}$, Chiquita Mardliyah ${ }^{3}$ \\ totokwahyu@umsida.ac.id ${ }^{1}$, ilmiusrotin@umsida.ac.id² \\ Communication Science Departement, Universitas Muhammadiyah Sidoarjo ${ }^{1}$, Public Administration \\ Departement, Universitas Muhammadiyah Sidoarjo ${ }^{2,3}$
}

\begin{abstract}
New media format has put the radio not only serves as a medium of information, education, and entertainment, but also as an interactive media and public sphere. The purpose of this study is to analyze and explain the radio as a public sphere to participate and interact and the influence of interactive media on community participation. This research method uses quantitative explanative with samples of 100 audiences who participated in the program "Kelana Kota" Radio Suara Surabaya. Analyzing technique used is multiple regression analysis with SPSS 20 program. The research results show that 1) radio has role as media to interact and exchange information with fellow audience and public space to participate in development of information society. Second, the most influential factors of participation are interactive media, assertiveness, and attitudes. The coefficient of influence of these three variables on participation is $40.2 \%$. Third, public participation in the radio public space in the form of access and delivery of information, supervision, partnership, consultation and dialogue. This research offers several novelties as follow: 1) interactive broadcasting media is a determinant to build social participation; 2) Assertive behaviour and acts are trigger for somebody to participate in the social development through interactive radio; 3) interactive radio can be a public space, interaction canal, empowerment media and active participating media for the society during the building of informative society.
\end{abstract}

Keywords: radio, public sphere, participate, community development.

\section{Introduction}

Radio is a kind of mass media, which is still recognized as functionally effective and efficient to be such communicative, informative, educative and entertaining [1]. Recently, radio is not only operated in one way communication, but instead, it has became as multi-direction and interactive [2][3], empowering [4], public space [5][6][8] and participative media [7][9][10]. Some broadcasting media which offer these kind of communication pattern are Radio Suara Kota Probolinggo, with its program "Program Laporo Rek", Radio Suara Sidoarjo, Jaringan Radio Komunitas Yogyakarta, Lembaga Penyiaran Publik (formerly known as Radio of Indonesian Republic), community based radio at Malang (such: Denta FM and Radio Jaya FM), and some other radio stations including Suara Surabaya. In this research, the discussion about the broadcasting radio offering a multi-directive communication will be focused only to Radio Suara Surabaya. 
Suara Surabaya (SS) radio station is chosen as the object of study due to its state as the pioneer of interactive radio (phone in programme) involving Surabayan citizens as active participant in information sharing through its program "Kelana Kota" Suara Surabaya. These people journalists can deliver their reports through the hotline 0315600000 and 0315683040 or through official website at http://www.suarasurabaya.net/radio, social media through www.facebook.com/e100ss, and www.twitter.com/e100ss. The program has successfully shape such an open, brave, honest, and firm society along with other goodness such greeting each other, cooperativeness, giving critical commentaries, information sharing, suggest and advice delivering, even openly to the government officers. This practice of interactive broadcasting is leading to an openness of communication, along with the highly expectation of information and complain delivery to the responsible person or institution.

Suara Surabaya (SS) has been handicapped by the character of its audience which are spontaneous and care. They are even able to influence one another during the report of traffic situations, especially through the speech style, knowledge and information. Audiences are not only reporting and delivering traffic situations, but they really know the real condition on the Surabaya streets, highways and some traffic jam spots, till various alternative and shortcut ways. This online information can obviously become such a supportive guide for the other audiences, and also shape positive social behaviour to cultivate good ethic among public transportation and traffic.

Based on this explanation, this research aimed to analyse and expose the influence of interactive media, people's motivation, assertive, people's behaviour toward the active participation in building informative society. This study gains its significance due to some following reasons: 1) audiences of Suara Surabaya are able to interact each other, sharing their information with the broadcaster and responsible stakeholders to gain appropriate response; 2) Suara Surabaya is connecting a wide-range network with other local radios across the East java province, Central Java and Jakarta such as Mandala FM Banyuwangi, Rama FM Bojonegoro, Sentral FM Lumajang, Nada FM Sumenep, Karimata FM Pamekasan, Tidar Sakti FM Bondowoso, Maja FM Mojokerto, Andika FM Kediri, Wijaya Kusuma FM Madiun, Suara Bojonegoro, Idola FM Semarang, Rakosa FM Yogyakarta, Mutiara FM Jember, Liur FM Tulungagung, and Sonora FM Jakarta; 3) Suara Surabaya has also gained its access with both central and regional government institutions, police department, military and other private agencies.

Some relevant theories are used to explain the goal of this study, such as theory of coorientation [11], democratic participant media [12][13], reasonable act [14], and social participation [15]. The theory of co-orientation is used to explain the relationship between media, government/responsible institutions and active audiences of the radio aiming to deal with the important issues taking place in surrounding environments. Some key issues which been discussed are recent traffic situations, cities live, traffic volume, traffic jam, accidents, traffic light problems and violations etc. Some trending topic issues are also being followed by these audiences, such as public service, criminality, government administration and social information.

Regarding to the democratic participant media, Mc-Quail [13] explained that citizens can individually or collectively have their rights to utilize radio as communication media, along with the rights to get appropriate radio service as they need. Organization and the content structure of the radio can't be overruled by any political power or state bureaucracy or any major organization in the country. The special character of democratic participant media is interactive and participative. Radio, as an interactive and participative media can be recognized as a 
democratic public place due to the state of information sharing between society members, open debate, brave reports of certain case after direct observation and critical discussion related to the up to date issues in surrounding environment. This public space is actually can be revitalized as sharing mode to express any social feeling freely, openly and bravely without any limitation caused by the unfinished development of informative society.

Social participation through the radio as a public space is the simple interpretation of social sovereignty (citizen power) during the state development. There are two type of social participation; active and passive [7]. Abadi stated that social participation is people involvement in the process of development to access and share information or needs through the media [14]. This involvement can include accessing and delivering information, surveillance, cooperation, dialogue and consultation.

Reasonable act which been done by society to be actively involved in the media broadcasting is obviously based on explicit reasons and considerations such change to a better public policy. These rational acts are explained by Ajzen and Fishbein in the theory of reasoned act [13]. The theory stated that somebody's act can influence other's behaviour through the process of decision making. Individual act, as active audiences, can be observed through motivations, assertive and attitude in the media broadcasting. Motivation has its indicators such as; interest, need and expectation of change. Assertive has its own indicators such as; honesty, responsibility, awareness and confidence. And so with the attitude, which can be indicated through ideas and concept toward specific object, emotional life or emotional evaluation toward the object or tendency to act.

Interactive media is a broadcasted media giving a space for the public audience and involving them as active contributor during the dynamic development of society life. Its existence in the convergent era of broadcasting technology, can offer need-based services as demanded by the public crossing any bureaucracy borders. The key of interactive media is the active participation from the audiences through information or aspiration sharing. Interactive media can also be measured through its content, punctuality and the type of utilized media such radio, web, streaming, facebook, twitter, and telephone/handphone. This study's hypotheses stated that interactive media, motivation, assertive and attitude can positively simultaneously influence the social participation during the effort to build informative society.

\section{Method}

The study is run under the scheme of explanative research using a sample containing 100 respondents who are all active and interactive audiences of the "Kelana Kota" Suara Surabaya. The primer data is taken from questionnaire distribution arranged in five variables. These variables are interactive media (X1), motivation (X2), assertive (X3), attitude (X4) and social participation (Y). Interactive media is explained through several indicators such as; content, punctuality, response, follow up and the utilized media for the interaction (telephone/HP, facebook, live streaming and twitter). Indicators which are used to measure motivation are interest, need to share information and expectation of change. Assertive can be measured through honesty, responsibility, awareness and confidence. The measurement of attitude are done through believes, ideas upon traffic information and transportation, individual emotion and tendency to act. Meanwhile, participation is measured through somebody's involvement to access and share information, surveillance, cooperation, consultation and dialogues. 
The data was taken on-line and off-line, and then being decoded, processed and examined through the validity and reliability test. The result of validity test shown that all items used inside the questionnaire are valid (with the value above 0.30 ). Hence, the result of reliability test for each variable showed the strong reliability as presented in table 1. This data analysis was done using multiplied linier regression through the SPSS ver.20.

Table 1. Result of reliability test for the research variables

\begin{tabular}{|c|c|c|}
\hline Variabel & Cronbach Alpa & Status \\
\hline Media Interaktif $\left(\mathrm{X}_{1}\right)$ & .767 & Reliable \\
\hline Motivasi $\left(\mathrm{X}_{2}\right)$ & .876 & Very Reliable \\
\hline Asertivitas $\left(\mathrm{X}_{3}\right)$ & .869 & Very Reliable \\
\hline Sikap $\left(\mathrm{X}_{4}\right)$ & .833 & Very Reliable \\
\hline Partisipasi $(\mathrm{Y})$ & .826 & Very Reliable \\
\hline
\end{tabular}

\section{Finding and Discussion}

\section{Public Space: radio as a new media}

There are at least four reasons caused East java province societies to likely become audience of Suara Surabaya, those are; interesting and entertaining songs (5\%); information related to economy, social, politics and culture (9\%), favourite broadcaster $(3 \%)$ and traffic conditions information across the region (83\%). The intensity of listening time are almost every time (36\%), rarely (30\%) and uncertain (only if possible) (34\%).

Age ranges of audiences are between 30-50 (70\%). Meanwhile, audiences from 20-30 are $28 \%$ and 51 above $2 \%$. Audience's profession are vary, among them are governmental official workers (PNS) (11\%), private sector workers (81\%), policeman $(2 \%)$ and teacher/lecturer $(6 \%)$. Educational background has also varied as follows; bachelor degree graduated (69\%), secondary school graduated (25\%) and Master degree graduated $(6 \%)$.

Location where audiences accessed the SS radio is also vary, among them are accessing in their office (23\%), in the car (53\%) and live streaming (24\%). Based on this data, we can analyse that SS radio audience are dominantly from the midle-class to upper-class society members. And in this midle-class group SS radio has gained its reputation as interactive media, public space and participative place to share information with other audiences anywhere online.

Audiences' motivation to participate in the programme "Kelana Kota" Suara Surabaya are the presence of self interest and need to the provided information related to the surrounding environment, mainly the traffic conditions or the public service. The active participation of SS audiences are back-boned by their expectation to get appropriate response and service from the responsible stakeholders, so that they can see such a better condition, conductivity fast, precisely and accurately in their surrounding environment.

The kind of support in the form of information sharing or interactive dialogue is among the positive attitude from the audiences toward the programme "Kelana Kota" Suara Surabaya. This attitude reflected believes, trusts, tendency to act and emotional bound among society through the SS radio, so that they can contribute actively in the programme. This positive attitude encouraged another active audience to be aware and confident to speak up, discuss, consult, debate, cooperate exchange information in the public space, and even doing surveillance toward the public facilities responsibly and honestly through the participative broadcasting media. SS radio, as a broadcasting media, has successfully empowered people as its journalists through its interactive channels such telephone/handphone, website, facebook, twitter, streaming and radio. 
And the most importantly, this interactive media can provide up to date news with punctuality to all audiences.

\section{Society member's participation}

People involvement as audiences in Kelana Kota Suara Surabaya is a form of people's ability to deliver their aspiration, information, and to do open dialogues in the era of democratic media. Society participation in the development of interactive broadcasting radio (Suara Suarabaya) includes access and information exchange, supervision, cooperation, consultation and empowerment. This involvement is mediated through the interactive broadcasting media and has achieved high level of cooperation, dialogues/consultation and empowerment (shown in figure 1).

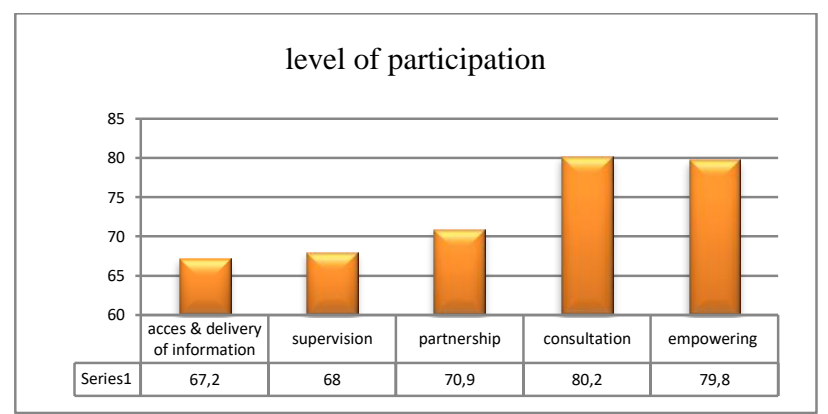

Fig 1. Society participations

SS radio which been utilizing interactive media such as facebook, twitter and live streaming has seemingly create a new community to be involved in the making of unlimited social relationship pattern with wide-range scope and transparency. This kind of social relationship pattern can possibly emerge a communication pattern know as co-orientation, which is described as the relationship between media, society members and government/private sectors dealing with key issues. The interactive radio can also become a democratic public space, where people are pleased to exchange any important information or to debate openly about the current issues in surrounding environment. People involvement in the radio as public space is considered as positive attitude to eagerly and competently communicate one to another. Eagerness and ability to communicate about expectation, feeling and thought must also preserve people rights. This is important since this assertive is presumably influential for the other member's participation in the radio.

The hypothesis stated that audience active involvement in SS radio is presumably influenced by interactive media, motivation, assertive and attitude has been exposed in table 2 . The result of hypothesis test, as presented in table 2 , showed that the use of interactive media, motivation, assertive and attitude are simultaneously and positively influential toward the society participation. Partially, several factors which are the most influential are interactive media $(27.9 \%)$, assertive $(26.7 \%)$ and attitude $(51.5 \%)$. The influence of these three variables toward the society participation in the development of informative society reached its significance of $\mathrm{t}$ hit 0.000 lesser than $\alpha(0.05)$ and regression coefficient $40.2 \%$. 
Table 2. Influential factors toward society participation

\begin{tabular}{|llccc|}
\hline No & \multicolumn{1}{c}{ Variabel } & $\begin{array}{l}\text { Regression } \\
\text { Coefficient }\end{array}$ & t-hit & Sig. \\
\hline 1 & Constant & 13.879 & 1,680 & 0,096 \\
\hline 2 & Interactive media (X1) & .279 & 2,204 & 0,030 \\
\hline 3 & Motivation (X2) & .135 & 1,508 & 0,135 \\
\hline 4 & Assertive (X3) & .267 & 3,648 & 0,000 \\
\hline 5 & Attitude (X4) & .515 & 3,280 & 0,001 \\
\hline
\end{tabular}

$\begin{array}{lll}\text { Note: } & & \\ \mathrm{N} & : 100 & \mathrm{R}: 0,653 \\ \mathrm{R} \text { Square } & : 0,426 & \text { Adjusted R Square }: 0,402 \\ \text { F count } & : 19.732 & \mathrm{df}=3 \quad \text { Sig F }: 0,000 \\ \text { Sig } \alpha & : 0,05 & \\ \text { Durbin - Watson } & : 1,65<1.949<2,35(\text { the absence of auto-correlation) } \\ \text { Data distribution } & : \text { Normal } & \\ \text { Equation model } & : & \\ \mathrm{Y}=13,879+0,279(\mathrm{X} 1)+0,135(\mathrm{X} 2)+0,267(\mathrm{X} 3)+0,515(\mathrm{X} 4)\end{array}$

Predictors : (Constan), interactive media, motivation, assertive, attitude Dependent Variable : society participation

Interactive media is influential for the society participation since the SS radio gives opportunities to the people to be actively involved in the process of information broadcasting. The radio has formed as new public space for audience to imagine, interact, discuss and participate in the information exchange, critics, suggestions, or responses. The same thing has also been explained by Hadi that the audiences in interactive media are no longer just a consumer, but instead, actively contribute like reporters [2].

Society participation in the broadcasting media is a part of local democratization which able to educate members of society in responding government policies related to the qualified environment development and more respected society. This statement is also supported by McQuail, that every single citizen has equal right to get information and service from the radio as they need [13].

Positive attitude from the society members reflected believes, emotional needs and tendency to act can awake people awareness toward the high qualified and sustainable development, and so as the assertive, honesty, responsibility, awareness and confidence. Assertive is a factor encouraging the society participation to use the interactive broadcasting media, not only on-air radio, but also social media of SS radio. Social media is also a public space providing unlimited chance, opportunities and comfortable space to share any kind of information like a reporter. It also give space for the people who are facing such a difficulties is arranging words or sentences, which sometimes make them being afraid to share information through the SS on air radio.

The novelty of this study are: 1) interactive broadcasting media is a determinant to build social participation; 2) Assertive behaviour and acts are trigger for somebody to participate in the social development through interactive radio; 3 ) interactive radio can be a public space, interaction canal, empowerment media and active participating media for the society during the building of informative 


\section{Conclusion}

The final conclusion of this study is that society participation in radio as public space has reached a very high level, known as citizen power, dialogue and cooperation. Citizen power is people ability to deliver critics, suggestion, support, objection or recommendation over certain policy or any effort done by the government/ responsible organization. The next participation level is interactive communication (dialogue) between active audience and the broadcaster/gatekeeper, and then between broadcasters with the responsible stakeholders which can directly heard openly by all audiences.

Cooperation is a pattern of social interaction between media and government/private sectors in discussing key issued related to the development process to gain any support or problem solving through the interactive radio broadcasting. Society participation in the development is influenced by the use of interactive broadcasting media, positive attitude, and assertive. The influence of these three variables reached the value of $42.2 \%$ in linier regression coefficient. The novelty of this study are: 1 ) interactive broadcasting media is a determinant to build social participation; 2) Assertive behaviour and acts are trigger for somebody to participate in the social development through interactive radio; 3) interactive radio can be a public space, interaction canal, empowerment media and active participating media for the society during the building of informative.

Acknowledgement. We hereby thank you to Universitas Muhammadiyah Sidoarjo for supporting our publication research.

\section{References}

[1] Azraqi, M. The function of local government broadcast radio (RSPD) in development (study at Delta Pawan District Ketapang Regency Kalimantan Barat Province. (2014) Jakarta : Tesis. Universitas Indonesia.

[2] Hadi, I.P. "Interactive Media Users as Maya Facts: Study of the Audience reception of Suara Surabaya.net as a Media. (2011). ASPIKOM Journal. Vol.1(3). P:231. http://jurnalaspikom.org.

[3] Yoanita, D and Fanny L. Accuracy in Citizen Journalism at Radio Suara Surabaya. (2014). Scriptura Journal. Surabaya : Universitas Kristen Petra. http://scriptura.petra.ac.id

[4] Tripambudi, S. "Community radio as an alternative media for community empowerment." Ilmu Komunikasi Journal. Vol.9 (3). 2011. P.317-337. http://repository.upnyk.ac.id

[5] Effendy, R. "Break down the potential of public broadcasting public spaces in efforts to democratize local communities." (2014). Reformasi Journal. Vol. 4 (2). https://www.researchgate.net/publication.

[6] Ispandriarno, L.S. and Olivia L. Research on the radio republic of Indonesia as a public space: issues of integrity and multiculturalism in election programs for young listeners. (2015). at http://e-journal.uajy.ac.id/eprints/8045/. Download: March,2, 2016

[7] Susilo, E.A. Optimizing the role of community radio as a public space \& crossstakeholder communication interaction media: "Study on Radio Komunitas Denta FM 
Sumbermanjing Kulon Pagak Regency dan Radio Jaya FM Mendalan Wangi Wagir Regency Malang Regency".

[8] Bucy, E.P and Kimberly S.G. "Media participation: a legitimizing mechanism of mass democracy." (2001). in New media and society. London: Sage Publication. Vol 3 (3). $\mathrm{P}: 357-380$

[9] Komariah, M. dan Totok W.A. "Effectiveness of programa "laporo rek" radio suara kota as a community participatory communication media in development in the Probolinggo City." (2015). dalam Jurnal Kanal. Vol.4 (1). P. 1-16. http://ojs.umsida.ac.id/index.php/kanal/article/view/311

[10] Abadi, T.W., Nunung P., Budi G. Performance e-government to increase community participation in infrastructure development in the Sidoarjo Regency. (2014). Yogyakarta : Jurnal KAWISTARA. Universitas Gadjah Mada

[11] Abadi, T.W., Nunung P., Budi G. "e-Government as new media of society participation in the development of Sidoarjo, Indonesia." at International Journal of Current Research. Vol. 7, Issue, 12, pp.24552-24561, December, (2015). http://www.journalcra.com/

[12] Blumler, J.G. Communication and Democracy: The Crisis Beyond and the Ferment Within. (1983). at https://onlinelibrary.wiley.com/doi/pdf/

[13] McQuail, D. \& Sven W. Communication Models for The Study of Mass Communications. (1984). New York \& London: Longman.

[14]Littlejohn, S.W \& Karen A.F. Theories of human of ccommunication. (2009). Eds.9. Singapore: Sage Publication

[15]Abadi, T.W. "Accessibility of public information based on e-government and community participation in the construction of road infrastructure in the Sidoarjo Regency." (2016). Disertasi. Yogdjakarta: UGM. http://etd.repository.ugm.ac.id 